Article

\title{
Promoting Sustainability Transparency in European Local Governments: An Empirical Analysis Based on Administrative Cultures
}

\author{
Andrés Navarro-Galera ${ }^{1}$, Mercedes Ruiz-Lozano ${ }^{2, *}$, Pilar Tirado-Valencia ${ }^{2}$ \\ and Araceli de los Ríos-Berjillos ${ }^{3}$ \\ 1 Financial Economics and Accounting Department, University of Granada, 18071 Granada, Spain; \\ angalera@ugr.es \\ 2 Departamento de Economía Financiera y Contabilidad, Universidad Loyola Andalucía, 14004 Córdoba, \\ Spain; ptirado@uloyola.es \\ 3 Departamento de Gestión Empresarial, Universidad Loyola Andalucía, 14004 Córdoba, Spain; \\ arios@uloyola.es \\ * Correspondence: mruiz@uloyola.es; Tel.: +34-957-222-150
}

Academic Editor: Yongrok Choi

Received: 15 December 2016; Accepted: 13 March 2017; Published: 15 March 2017

\begin{abstract}
Nowadays, the transparency of governments with respect to the sustainability of public services is a very interesting issue for stakeholders and academics. It has led to previous research and international organisations (EU, IMF, OECD, United Nations, IFAC, G-20, World Bank) to recommend promotion of the online dissemination of economic, social and environmental information. Based on previous studies about e-government and the influence of administrative cultures on governmental accountability, this paper seeks to identify political actions useful to improve the practices of transparency on economic, social and environmental sustainability in European local governments. We perform a comparative analysis of sustainability information published on the websites of 72 local governments in 10 European countries grouped into main three cultural contexts (Anglo-Saxon, Southern European and Nordic). Using international sustainability reporting guidelines, our results reveal significant differences in local government transparency in each context. The most transparent local governments are the Anglo-Saxon ones, followed by Southern European and Nordic governments. Based on individualized empirical results for each administrative style, our conclusions propose useful policy interventions to enhance sustainability transparency within each cultural tradition, such as development of legal rules on transparency and sustainability, tools to motivate local managers for online diffusion of sustainability information and analysis of information needs of stakeholders.
\end{abstract}

Keywords: sustainability; transparency; local governments; administrative cultures; e-government

\section{Introduction}

During the last years, various authors [1-3] have concluded that on a global level, the effect of the economic crisis on government finances has transformed public-policy sustainability into a topic of substantial concern for citizens, politicians, managers and other stakeholders. In fact, against the backdrop of worldwide government financial crises, several international bodies [4-8] have emphasised the need to adopt good governance practices for public policies of sustainability and encourage transparency regarding social, economic and environmental information $[9,10]$.

In this line, numerous studies have emphasised that transparency of public policies is a key element of good governance $[2,3,9,11,12]$. Simultaneously, various international bodies $[5,7]$ 
recommend public-sector entities to adopt information dissemination practices that respond to increasing stakeholder demands. In recognition of the importance of transparency and accountability, numerous countries have adopted laws to strengthen communication between government and citizens with the goal of guaranteeing public access to government information [13-15].

More specifically, prior research has concluded that the study of transparency practices with respect to sustainability of public policies is particularly important for local governments due to their direct contact with citizens, the volume of resources that the governments manage and the tenuous government financial circumstances $[10,16,17]$. Similarly, studies $[3,14,18]$ have recognised the timeliness and relevance of studying e-government contributions to online transparency of sustainability for local governments.

However, despite the interest in studying online transparency regarding sustainability of public services, few studies have focused on the online dissemination of this type of information $[12,19,20]$. Previous studies have proposed the usefulness of comparing sustainability transparency practices across different contexts given that the administrative cultures of different countries influence the level of government openness toward citizens and their accountability practices [21].

Thus, to advance the study of the sustainability transparency practices of local governments, it would be useful to examine what several authors refer to as the three main cultural traditions in public administration in Western democracies: Anglo-Saxon, Southern European and Nordic or Scandinavian [22-24].

Based on this motivation, the present paper seeks to identify political actions useful to improve the practices of transparency for economic, social and environmental sustainability in European local governments, studying the three predominant public administration styles. We perform a comparative analysis of online transparency regarding sustainability in these three cultural contexts by studying the websites of 72 local governments which are grouped according to whether they belong to Anglo-Saxon, Southern European or Nordic countries. This approach enables us to understand the contributions of each type of administrative culture to government sustainability transparency through the study of the conditioning factors of the three predominant administrative styles. Our empirical results support the identification of some useful policy interventions to enhance sustainability transparency within each cultural tradition, such as development of legal rules on transparency and sustainability, tools to motivate local managers for online diffusion of sustainability information and analysis of information needs of stakeholders.

\section{Administrative Culture and Its Effect on Government Transparency}

According to the European Union [6], transparency should be understood as the right of citizens to access government information. Under this same approach, IFAC [5] has defined transparency in terms of information disclosed regarding not only the actions taken, but also the comprehension of these actions by stakeholders and the responses made by them.

As stated in this definition of transparency and using the New Public Management approach during recent decades, a significant number of countries has implemented administrative reforms with the goal of promoting transparency as a tool for accountability, with advocacy particularly directed at local governments [25-27]. More recently, using a more modern approach (Public Value Governance) in which citizens are viewed as participants in solving government problems, transparency has played an even more significant role insofar as citizens must be well informed to strengthen their active involvement in decisions regarding public matters and to make decisions in support of their government leaders [11,28].

In each country, administrative reforms have been developed differently. As previous researchers have observed [22,29], styles of administrative culture have influenced the role of the State and the focus of transparency and accountability (by way of different legal frameworks and organisational structures) such that countries with the same cultural traditions have implemented reforms in similar ways $[30,31]$. 
Accordingly, several authors have discerned three main administrative cultures in Europe (i.e., Anglo-Saxon, Southern European and Nordic) in which concepts of transparency and accountability, the way in which these concepts are applied, and government commitment play essential roles $[25,26]$. In fact, certain authors have concluded that administrative traditions significantly affect the dissemination of government information [32,33]. Although these administrative styles can be disaggregated by adding other types such as the Germanic countries, in this paper, we have taken the three administrative traditions that are considered to be principal or predominant in international organizations and previous works [23,34-36]. However, authors Pina, Torres and Royo [37] and Hammerschmid and Meyer [38] consider the Germanic countries within continental countries taking into account their similarities in administrative structures.

In this sense, following Navarro and Rodríguez [22], Howlett [39] or Kickert [23], the administrative cultures that differ the most one from the other are the Anglo-Saxon countries and the Southern European countries, whose governments employ different styles of public management. Whereas Anglo-Saxon culture uses a model based on participation, Southern European culture uses a reactive, enforcement-based model, which can affect the transparency practices of public entities in significant ways.

Additionally, differences among transparency practices can originate from each country's normative context. In fact, the implementation of laws regarding citizen access to government information has occurred at very different times in different countries. For example, the United Kingdom's freedom of information law was passed in 2000, Italy's in 1990, Norway's in 1970 and Finland's in 1951 [13].

In Anglo-Saxon countries, governments opt for a competence focus conceiving the citizen as a "client" and emphasising transparency, which can generate increased trust in government [40]. In contrast, Southern European governments pay less attention to transparency and accountability and their public administrations are organised according to bureaucratic legal norms [41].

According to CSR Europe [42], in Nordic cultures, special efforts are exerted to promote corporate social responsibility, in which transparency is a fundamental concept, and to incorporate diverse aspects of transparency into their regulations. These countries have been influenced by the Southern European and Anglo-Saxon public administration traditions and therefore can be considered to be hybrids of these two types of public administration [23,43]. Compared with Anglo-Saxon countries, Nordic countries have a substantially more pragmatic vision of reforms. They develop regulatory changes to promote quality services and envision an active role for stakeholders in the management and evaluation of public policies. According to the model defended by Bryson et al. [28] and Greco et al. [11], this approach should be combined with enhanced government transparency.

In investigations of the different implications of government transparency, a number of authors $[16,44,45]$ have analysed the dissemination of financial information by local governments in specific countries that belong to the same administrative culture. However, despite recommendations from international bodies, none of these studies have analysed the disclosure of information regarding the sustainability or performed a comparative analysis of different cultural contexts. Thus, our research objective is timely and valuable.

\section{Empirical Study}

\subsection{Sample Selection}

As previously indicated, a country's type of administrative culture can influence a government's level of openness, the relations of public entities with the stakeholders and the emphasis placed on transparency. Building on that basis, our empirical study performs a comparative analysis of the sustainability-related content disseminated on websites of a group of local governments. These local governments are divided into three groups that represent the three European cultural contexts: Anglo-Saxon, Southern European and Nordic. We chose these three types of administrative 
culture because reforms have followed certain patterns in countries that have common administrative traditions and share certain cultural values and because this feature has contributed to improving government transparency [41]. These three administrative styles can be disaggregated by adding other types such as the Germanic countries. However, in our sample, we have taken only the three administrative traditions that are considered main or predominant by international organizations and previous works [23,34-36].

Our study sample includes 10 countries as follows: Anglo-Saxon countries (the United Kingdom and Ireland), Southern European countries (Italy, Portugal and Spain) and Nordic countries (Norway, Finland, Denmark, Sweden and the Netherlands).

Using contributions from a wide panel of international experts, the Centre for Law and Democracy [13] has developed the Global Right to Information Rating. In this ranking system, experts analyse national access-to-information laws in 102 countries and score the quality of each legal framework using 61 indicators divided into seven sections (i.e., right of access, scope, procedure requests, exceptions and refusals, appeals, sanctions and protections and promotional measures). The maximum cumulative core is 150 . As shown in Table 1, Nordic countries were generally the first to adopt government transparency laws. These countries are followed by two continental countries (Portugal and Italy) and one Anglo-Saxon country (UK) as well as more recently by Ireland and Spain. However, the scores for the quality of transparency-related legal frameworks do not follow this order. Instead, Anglo-Saxon countries occupy the highest positions, on the whole, and Southern European countries occupy the lowest, with Nordic countries in intermediate positions. Nevertheless, the first position is occupied by a Nordic country (Finland). Therefore, the exception is Finland, which achieved the highest score of all 10 countries in the sample.

Table 1. Laws for access to public information and rating.

\begin{tabular}{ccc}
\hline Countries & $\begin{array}{c}\text { Year of Publication } \\
\text { of the Law }\end{array}$ & $\begin{array}{c}\text { Global Right Information } \\
\text { Rating (Max. 150) }\end{array}$ \\
\hline United Kingdom & 2000 & 100 \\
Ireland & 2014 & 95 \\
Italy & 1990 & 57 \\
Portugal & 1993 & 73 \\
Spain & 2013 & 73 \\
Norway & 1970 & 78 \\
Finland & 1951 & 105 \\
Denmark & 1970 & 64 \\
Sweden & 1766 & 92 \\
Netherlands & 1978 & 82 \\
\hline
\end{tabular}

We chose local governments for several reasons. First, international organisations consider local government to be a highly suitable level of government for the study of sustainability transparency [46]. Likewise, in its Fiscal Sustainability Report, the EU [7] indicated that in light of the worrisome situation for public finances, it is necessary to continue examining sustainability issues in local governments. Finally, findings from prior studies indicate that local governments are a highly suitable type of government for the study of sustainability practices because their direct contact with citizens makes it easier for them to become acquainted with different stakeholder demands [12,47].

Our sample consists of 72 local governments of the 10 countries mentioned above. Local governments with large populations have been selected, except in some cases in which they have been chosen because of their economic impact and the resources they manage, seeking the representativeness of the sample. These local governments are distributed among the administrative cultures as follows: 25 Anglo-Saxon governments, 26 Southern European governments and 21 Nordic governments. As in prior studies on local government transparency $[16,20,33]$, we have chosen 
municipalities with large populations for the following reasons: (a) EU [7] recommends studying sustainability in larger municipalities, which are particularly subject to the negative effects of an aging population and to high levels of debt and deficit; (b) larger municipalities provide a wider range of services; however, at the same time, the provided services tend to be more homogenous; (c) these municipalities have greater access to new technologies and make greater use of them; (d) the administrative staff typically has a greater degree of specialisation and professionalism than that of smaller municipalities; (e) these municipalities have a larger number and variety of stakeholders; (f) the larger volume of managed resources, which suggests that more investments should be dedicated to ensuring sustainability.

\subsection{Methodology}

At a global level, e-government practices play a crucial role in increasing government transparency by facilitating free and universal access to information via the Web $[14,48]$.

Today, higher levels of transparency may be associated with increased confidence in an organisation's commitment to sustainability and, in many cases, this confidence is acquired by increasing the level of disclosure [49]. The Web enables public officials to provide a larger quantity of information and to do it in a more frequently and accessible way, thus removing barriers between citizens and government [18]. More specifically, Estevez and Janowski [50] note that the Internet and the Web are key elements in the link between e-government and sustainable development. Likewise, Janowski [51] identifies that stages of Digital Government Evolution Model can be characterized by variables like the internal transformation or the relationships between government and various non-government stakeholders, and that the context can influence in the transformation.

Thus, and in line with previous studies on government information $[19,20,47]$, in our empirical study we measure transparency according to the volume of online information published on the websites of the 72 local governments of our sample, including all departments.

To measure the volume of sustainability information available on each website, we use standard guidelines and recommendations issued by international bodies. The OECD [48], the World Bank [8] and the UN Global Compact [52] have published useful frameworks. However, the G3 version of the GRI guidelines [53] was long considered to be the fundamental standard for the dissemination of sustainability information [54].

Particularly in the public sphere, Bernhart [55] and Beare et al. [2], among others, assert that these guidelines currently have the largest impact on public-sector entities and the number of public organisations that implement these recommendations has dramatically increased.

Therefore, in our empirical study, we use the sustainability report model recommended by the GRI, specifically the items proposed in the G3 and G4 guidelines, as well as those included in specific supplements published for public entities [53,56,57], thus obtaining a set of indicators to measure economic, social and environmental aspects. Our questionnaire consists of 75 items structured into four blocks: general information ( 28 items), economic information ( 24 items), social information (10 items) and environmental information (13 items), of which the content and results are shown in Appendix A.

We employed a measurement system based on website content analysis to study whether the websites of the 72 local governments disseminate the items included in the questionnaire. We assign a value of 1 to each item if the information is published on a given local government website and a value of 0 if the information is not published. The method for data collection consisted of: first, two researchers sought the information within websites separately; second, the information indicated was pooled; in case of divergence, a value of 1 was selected, since it meant one of the two researchers had found the variable on the web. This process of data collection has been validated in previous research [58].

By this we obtain a numerical indicator for each website via the sum of the scores obtained for the different items. This sum is the value of our sustainability transparency indicator for the local governments being studied. Additionally, to guarantee the representativeness of the comparative 
results, we calculate the average frequencies using the sum of items within each block, not the sum of items from the entire questionnaire.

This method enables us to perform a descriptive study based on the analysis of frequencies to determine the level of sustainability information disclosure in general terms, by administrative culture, by cities, by block or type of information and for each of the defined variables or items. Additionally, we have developed a ranking of countries according to their indices of sustainability information dissemination. For this purpose, we treat each block as $25 \%$, based upon Dutta and Lawson's [59] conclusions. We have assigned the same weight (25\%) to each block because previous research $[32,59,60]$ concluded that when the number of items is different in each block of the questionnaire, it is necessary to guarantee homogeneity by means of the balance in each block so that the comparative analysis between countries belonging to different administrative styles is relevant.

Once the frequencies of all of the sustainability transparency indicators were obtained, we performed a comparative analysis of the local governments that represent each of the three administrative cultures. To this end, we use variance analysis, which is considered a useful statistical test to determine whether significant differences exist between the values obtained by different groups, as observed by Zar [61]. In fact, variance analysis has been frequently used in previous studies [62]. We also perform multiple contrasts or post-hoc comparisons in order to identify the values that differ most among groups. With this goal in mind and following authors who specialise in statistical analysis when there was homogeneity of variance, we used Tukey's honest test (HSD) and when the variance was not homogeneous, we used the Games Howell test [61,63].

\section{Empirical Results}

Individually applying content analysis to the websites of the 72 local governments in our sample, we obtained the data included in Table 2, which presents the indices of sustainability transparency for the three analysed groups of local governments (i.e., Anglo-Saxon, Nordic and Southern European) differentiated by blocks: general, economic, social and environmental. The individual frequencies for each of the 75 items in detail, differentiating by administrative culture are shown in Appendix A.

Table 2. Disclosure information using three administrative cultures.

\begin{tabular}{|c|c|c|c|c|c|}
\hline Blocks & $\begin{array}{l}\text { Anglo-Saxon \% } \\
\text { (Transparency } \\
\text { Indices) }\end{array}$ & $\begin{array}{l}\text { Nordic Countries } \\
\text { \% (Transparency } \\
\text { Indices) }\end{array}$ & $\begin{array}{c}\text { Sourthern European } \\
\text { \% (Transparency } \\
\text { Indices) }\end{array}$ & $\begin{array}{c}\text { Average \% } \\
\text { (Transparency } \\
\text { Indices) }\end{array}$ & $\begin{array}{c}\text { Standard } \\
\text { Desviations }\end{array}$ \\
\hline $\begin{array}{l}\text { Block 1: General } \\
\text { Information on } \\
\text { Sustainability ( } 28 \text { ítems) }\end{array}$ & 70.1 & 49.8 & 59.9 & 62.5 & 10.56 \\
\hline $\begin{array}{l}\text { Block 2: Economic } \\
\text { Information ( } 24 \text { ítems) }\end{array}$ & 72.3 & 33.0 & 59.8 & 58.2 & 19.74 \\
\hline $\begin{array}{l}\text { Block 3: Social } \\
\text { Information (10 ítems) }\end{array}$ & 73.2 & 41.9 & 57.3 & 59.4 & 15.75 \\
\hline $\begin{array}{l}\text { Block 4: Environmental } \\
\text { Information (13 ítems) }\end{array}$ & 54.2 & 44.3 & 30.2 & 52.12 & 15.08 \\
\hline Total & 67.45 & 42.25 & 51.8 & 58.05 & 0.14 \\
\hline
\end{tabular}

As can be noted from the aggregated data of the three administrative cultures, the analysed local governments achieve great transparency on average, for general information on sustainability (62.5\%), followed by social information (59.4\%) and economic information (58.2\%), with environmental transparency occupying the last position (52.12\%). Additionally, as the standard deviations included in Table 2 illustrate, the level of uniformity among results differs between blocks. Economic information had the greatest dispersion of results (19.74), whereas general information was the most uniform (10.46). Social and environmental information was similarly situated in between (15.75 and 15.08). 
These results indicate a common pattern of behaviour given that the websites of the 72 analysed local governments, as instruments of e-government, are being used as tools of sustainability information dissemination.

However, the differences between levels of transparency are not similar across comparisons (Table 3). If we compare transparency indices in pairs (i.e., two by two), the Anglo-Saxon-Southern European and Southern European-Nordic distances between transparency indices are very similar for general information $(10.2 \%$ and $10.1 \%)$ and social information (15.9\% and $15.4 \%)$. In contrast, these distances are significantly greater in the case of economic sustainability $(12.5 \%$ for Anglo-Saxon-Southern European variance and 26.8\% for Southern European-Nordic variance) and in the case of environmental sustainability ( $24 \%$ and $-14.1 \%$, respectively).

Table 3. Differences of levels of transparency between cultures.

\begin{tabular}{lccc}
\hline & $\begin{array}{c}\text { Anglo-Saxon Sourthern } \\
\text { European \% }\end{array}$ & $\begin{array}{c}\text { Anglo-Saxon } \\
\text { Nordic \% }\end{array}$ & $\begin{array}{c}\text { Sourthern European } \\
\text { Nordic \% }\end{array}$ \\
\hline $\begin{array}{l}\text { Block 1: General Information } \\
\text { on Sustainability }\end{array}$ & 10.2 & 20.3 & 10.1 \\
\hline $\begin{array}{l}\text { Block 2: Economic } \\
\text { Information }\end{array}$ & 12.5 & 39.3 & 26.8 \\
\hline Block 3: Social Information & 15.9 & 31.3 & 15.4 \\
\hline $\begin{array}{l}\text { Block 4: Environmental } \\
\text { Information }\end{array}$ & 24.0 & 9.9 & -14.1 \\
\hline
\end{tabular}

These results appear to corroborate the conclusions of studies, such as those by Kickert [23] or Lozano et al. [43], that characterise the Nordic style of government as a mixed style (with Anglo-Saxon and Southern European cultural influences). Our results also represent advances of previous findings. From our results, it seems that positive Anglo-Saxon cultural influence on Nordic governments has been substantially stronger with respect to the dissemination of environmental information. However, the negative effect of Southern European culture has been stronger regarding the disclosure of economic information. Nevertheless, we have not obtained empirical evidence to contradict the findings of Navarro and Rodríguez [22] or Kickert [23], who concluded that the greatest differences between administrative cultures are between Anglo-Saxon and Southern European countries.

In any case, these differences between administrative cultures are consistent with the different transparency indices that are presented in the different blocks for each culture (Table 2). In Anglo-Saxon governments, social information $(73.2 \%)$ and economic information $(72.3 \%)$ are disseminated at the highest rates, followed by general information $(70.1 \%)$ and, at a greater distance, environmental information (54.2\%). However, in the Southern European governments, although environmental information is also disseminated $(44.3 \%)$, the highest level of dissemination occurs with general information (59.9\%), followed closely by economic information (59.8\%) and social information (57.3\%).

This uneven behaviour regarding sustainability transparency can also be observed among the Nordic governments in which the highest level of dissemination occurs with general information $(49.8 \%)$, followed by environmental information (44.3\%), social information (41.9\%) and, at a much greater distance, economic information (33\%).

Following the Fukuyama essays [64], it is interesting to analyse the relationship between the level of administrative corruption in the countries and the sustainability transparency index, as Table 4 shows for EU countries. The comparison of our empirical results with the Transparency International "Transparency Perception Index" (2016) shows that the level of administrative corruption does not seem to be significantly influencing the governments' behaviour related to the diffusion of sustainability information. In average values, according to the Corruption Perception Index, the Nordic countries have the lowest levels of corruption (86.6 points on a maximum of 90 and position 2.8 of 28). In contrast, the Nordic countries have the lowest sustainability transparency index. However, Southern European countries have higher rates of perceived corruption than the Nordic countries 
(55.6 points and position 18.6) but their transparency index is higher than this index in Nordic countries. Similarly, the Anglo-Saxon countries have the highest sustainability transparency index and yet their level of administrative corruption is somewhat higher than the level of the Nordic countries (77 points and position 7.5). In parallel, this comparative analysis also reveals our results do not allow to support the influence of the level of sustainability transparency on the level of administrative corruption.

Table 4. Comparison between Sustainability Transparency Index and Corruption Perceptions Index.

\begin{tabular}{|c|c|c|c|c|c|}
\hline \multirow[b]{2}{*}{ Countries } & \multirow[b]{2}{*}{$\begin{array}{c}\text { Sustainability } \\
\text { Transparency } \\
\text { Index }\end{array}$} & \multicolumn{4}{|c|}{ Corruption Perceptions Index } \\
\hline & & $\begin{array}{c}\text { Points } \\
\text { (Max. 100) }\end{array}$ & $\begin{array}{c}\text { Average Points by } \\
\text { Administrative } \\
\text { Cultures }\end{array}$ & $\begin{array}{c}\text { Position } \\
\text { (28 Countries) }\end{array}$ & $\begin{array}{c}\text { Average Position } \\
\text { by Administrative } \\
\text { Cultures }\end{array}$ \\
\hline $\begin{array}{l}\text { United } \\
\text { Kingdom }\end{array}$ & 0.67 & 81 & \multirow{2}{*}{77} & 5 & \multirow{2}{*}{7.5} \\
\hline Ireland & 0.69 & 73 & & 10 & \\
\hline Italy & 0.60 & 47 & \multirow{3}{*}{55.6} & 26 & \multirow{3}{*}{18.6} \\
\hline Portugal & 0.67 & 62 & & 13 & \\
\hline Spain & 0.51 & 58 & & 17 & \\
\hline Norway & 0.60 & 83 & \multirow{5}{*}{86.6} & 4 & \multirow{5}{*}{2.8} \\
\hline Finland & 0.46 & 89 & & 2 & \\
\hline Denmark & 0.44 & 90 & & 1 & \\
\hline Sweden & 0.39 & 88 & & 3 & \\
\hline Netherlands & 0.26 & 83 & & 4 & \\
\hline
\end{tabular}

If we examine the country rankings included in Table 5, the added indices reveal that the local governments with the greatest sustainability transparency are Anglo-Saxon (Ireland, 0.69; the United Kingdom, 0.67), whereas those with least transparency are the local Nordic governments (Netherlands, 0.26; Sweden, 0.39; Denmark, 0.44). Norway is an exception. Its local governments produce an aggregate index of 0.60 , greater than Italy $(0.60)$ and Spain $(0.51)$, which are Southern European countries.

To properly interpret our empirical results, it is necessary to take into account that the country indexes are based on the analysis of local governments, not including other levels of government, as shown in the tables above.

The results of the levels of dissemination of information on sustainability of cities show that in block I on general information, the indexes are intermediate levels, except for the city of Palermo $(92.9 \%)$, which stands out for its commitment in this dimension. Block II of economic information highlights the English city of Stevenage, and the Italians Milano and Padova all with an index of 91.7\%. On the contrary, the Nordic cities of Espoo (12.5\%), Le Hague (4.2\%) and Utrecht (12.5\%) have very low rates. The city of Eindhoven does not provide any of the information analysed in this dimension $(0 \%)$.

Some local governments in the UK and Ireland are highlighted for their transparency in block III on social issues, with very high rates $(90 \%$ in Belfast, Bradford, Edinburgh, Exeter, Plymouth and Worcester) against cities like Malmoe $(10 \%)$ or Catonia $(10 \%)$.

Finally, in block IV of environmental information, the most extreme situations are presented. In addition to cities that comply with $100 \%$ of the items analysed (Dublin, Trondheim and Firenze) or which present very high values such as Wirral (92.3\%), others appear with a low level of transparency such as Uppsala $(7.7 \%)$ and Spanish cities of Granada $(7.7 \%)$, Seville $(7.7 \%)$ and Valencia $(7.7 \%)$. Some cities do not provide this type of information, such as the cities of Utrecht, Eindhoven and Naples ( $0 \%)$. 
Table 5. Disclosure information by cities, countries and blocks of contents.

\begin{tabular}{|c|c|c|c|c|c|}
\hline & Block I & Block II & Block III & Block IV & Total Index \\
\hline Dublin & 46.4 & 66.7 & 50.0 & 100.0 & \multirow{3}{*}{0.69} \\
\hline Belfast & 75.0 & 66.7 & 90.0 & 53.8 & \\
\hline Ireland & 60.7 & 66.7 & 70.0 & 76.9 & \\
\hline Birminghan & 42.9 & 58.3 & 50.0 & 38.5 & \multirow{24}{*}{0.67} \\
\hline Bradford & 67.9 & 58.3 & 90.0 & 38.5 & \\
\hline Brigthon & 78.6 & 79.2 & 70.0 & 84.6 & \\
\hline Bristol & 71.4 & 87.5 & 80.0 & 46.2 & \\
\hline Cardiff & 67.9 & 50.0 & 50.0 & 46.2 & \\
\hline Coventry & 78.6 & 83.3 & 80.0 & 30.8 & \\
\hline Derry & 64.3 & 54.2 & 70.0 & 38.5 & \\
\hline Edinburgh & 64.3 & 70.8 & 90.0 & 61.5 & \\
\hline Exeter & 71.4 & 66.7 & 90.0 & 53.8 & \\
\hline Glasgow & 82.1 & 83.3 & 70.0 & 38.5 & \\
\hline Leeds & 64.3 & 70.8 & 90.0 & 38.5 & \\
\hline Leicester & 82.1 & 83.3 & 80.0 & 46.2 & \\
\hline Liverpool & 75.0 & 70.8 & 70.0 & 53.8 & \\
\hline London & 78.6 & 62.5 & 80.0 & 46.2 & \\
\hline Manchester & 39.3 & 54.2 & 60.0 & 23.1 & \\
\hline NewCastle & 85.7 & 83.3 & 80.0 & 38.5 & \\
\hline Nottingham & 78.6 & 75.0 & 80.0 & 38.5 & \\
\hline Plymouth & 75.0 & 75.0 & 90.0 & 84.6 & \\
\hline Sheffield & 67.9 & 75.0 & 60.0 & 53.8 & \\
\hline Stevenage & 75.0 & 91.7 & 70.0 & 76.9 & \\
\hline Stoke-on-trend & 71.4 & 79.2 & 30.0 & 69.2 & \\
\hline Wirral & 71.4 & 79.2 & 70.0 & 92.3 & \\
\hline Worcester & 78.6 & 83.3 & 90.0 & 61.5 & \\
\hline United Kindom & 71.0 & 72.8 & 73.5 & 52.2 & \\
\hline Copenhagen & 50.0 & 37.5 & 50.0 & 46.2 & \\
\hline Odense & 60.7 & 37.5 & 50.0 & 30.8 & \\
\hline Aalborg & 53.6 & 33.3 & 30.0 & 46.2 & 0.44 \\
\hline Denmark & 54.8 & 36.1 & 43.3 & $\begin{array}{l}40.2 \\
41.1\end{array}$ & \\
\hline Helsinki & 50.0 & 62.5 & 60.0 & 69.2 & \\
\hline Espoo & 53.6 & 12.5 & 30.0 & 53.8 & \\
\hline Turku & 60.7 & 37.5 & 50.0 & 61.5 & \\
\hline Tempere & 57.1 & 37.5 & 50.0 & 61.5 & 0.46 \\
\hline Oulu & 39.3 & 29.2 & 30.0 & 15.4 & \\
\hline Finland & 52.1 & 35.8 & 44.0 & 52.3 & \\
\hline Stockholm & 53.6 & 41.7 & 50.0 & 77.0 & \\
\hline Malmoe & 50.0 & 33.3 & 10.0 & 38.5 & \\
\hline Goteborg & 32.1 & 41.7 & 30.0 & 23.1 & 0.39 \\
\hline Uppsala & 46.4 & 41.7 & 40.0 & 7.7 & \\
\hline Sweden & 45.5 & 39.6 & 32.5 & 36.6 & \\
\hline Le Hague & 50.0 & 4.2 & 50.0 & 23.1 & \\
\hline Utrecht & 42.9 & 12.5 & 20.0 & 0.0 & \\
\hline Eindhoven & 25.0 & 0.0 & 20.0 & 0.0 & \\
\hline Amsterdam & 39.3 & 29.2 & 30.0 & 61.5 & 0.26 \\
\hline Rotterdam & 35.7 & 16.7 & 30.0 & 30.8 & \\
\hline Netherlands & 38.6 & 12.5 & 30.0 & 23.1 & \\
\hline Bergen & 42.9 & 37.5 & 50.0 & 61.5 & \\
\hline Oslo & 50.0 & 41.7 & 90.0 & 76.9 & \\
\hline Trondheim & 85.7 & 54.3 & 60.0 & 100.0 & 0.60 \\
\hline Stavanger & 67.9 & 50.0 & 50.0 & 46.2 & \\
\hline Norway & 61.6 & 45.9 & 62.5 & 71.2 & \\
\hline
\end{tabular}


Table 5. Cont.

\begin{tabular}{|c|c|c|c|c|c|}
\hline & Block I & Block II & Block III & Block IV & Total Index \\
\hline Granada & 46.4 & 25.0 & 50.0 & 7.7 & \\
\hline Malaga & 53.6 & 54.2 & 50.0 & 84.6 & \\
\hline Seville & 39.3 & 45.8 & 50.0 & 7.7 & \\
\hline Zaragoza & 46.4 & 50.0 & 50.0 & 76.9 & \\
\hline Oviedo & 46.4 & 45.8 & 50.0 & 30.8 & \\
\hline Barcelona & 60.7 & 62.5 & 60.0 & 76.9 & 0.51 \\
\hline La Coruña & 46.4 & 58.3 & 70.0 & 30.8 & \\
\hline Madrid & 53.6 & 83.3 & 70.0 & 46.2 & \\
\hline Valencia & 42.9 & 37.5 & 60.0 & 7.7 & \\
\hline Vitoria & 67.9 & 70.8 & 70.0 & 69.2 & \\
\hline Spain & 50.4 & 53.3 & 58.0 & 43.9 & \\
\hline Brescia & 67.9 & 83.3 & 70.0 & 69.2 & \\
\hline Firenze & 78.6 & 83.3 & 60.0 & 100.0 & \\
\hline Milano & 78.6 & 91.7 & 50.0 & 69.2 & \\
\hline Padova & 78.6 & 91.7 & 80.0 & 76.9 & \\
\hline Salerno & 75.0 & 16.7 & 60.0 & 61.5 & \\
\hline Torino & 78.6 & 79.2 & 80.0 & 53.8 & \\
\hline Bari & 78.6 & 70.8 & 70.0 & 38.5 & \\
\hline Palermo & 92.9 & 83.3 & 70.0 & 38.5 & 0.60 \\
\hline Roma & 42.9 & 58.3 & 40.0 & 53.8 & \\
\hline Catonia & 25.0 & 50.0 & 10.0 & 30.8 & \\
\hline Verona & 53.6 & 62.5 & 40.0 & 69.2 & \\
\hline Bologna & 57.1 & 37.5 & 60.0 & 53.8 & \\
\hline Genova & 57.1 & 37.5 & 40.0 & 69.2 & \\
\hline Naples & 50.0 & 25.0 & 40.0 & 0.0 & \\
\hline Italy & 65.3 & 62.2 & 55.0 & 56.0 & \\
\hline Lisbon & 67.9 & 75.0 & 70.0 & 53.8 & \\
\hline Porto & 71.4 & 75.0 & 70.0 & 53.8 & 0.67 \\
\hline Portugal & 69.6 & 75.0 & 70.0 & 53.9 & \\
\hline
\end{tabular}

Likewise, to proceed to the analysis of variance, we used the scores achieved by the local governments of each country, belonging to each of the three cultures, for each of the four analysed blocks to obtain the results shown in Table 6. As can be observed, the results of variance analysis support the position that the hypothesis of the equality of mean values should be rejected because the values that correspond to three of the four types of studied information (i.e., general, economic and social) reveal statistically significant differences between the local governments that represent the three analysed cultural contexts (i.e., Anglo-Saxon, Southern European and Nordic). However, the results of the variance analysis for environmental information dissemination indicate that the hypothesis of the equality of means should be accepted because the differences are not statistically significant.

Table 6. Analysis of variance.

\begin{tabular}{cccccc}
\hline & SS & df & MSS & F & P \\
\hline Block 1 & 0.4728 & 2 & 0.236 & 12.222 & 0.000 \\
Block 2 & 1.819 & 2 & 0.909 & 31.498 & 0.000 \\
Block 3 & 1.122 & 2 & 0.561 & 20.836 & 0.000 \\
Block 4 & 0.114 & 2 & 0.057 & 0.949 & 0.392 \\
\hline
\end{tabular}

In addition, as reflected in Table 7, we have extended this analysis to identify the values that differ most among themselves. We perform multiple contrasts or post-hoc comparisons. Previously, we tested for homogeneity of variance; the test results indicate that variance is homogeneous in the indices 
of general information, social and environmental transparency. In contrast, in the case of economic information, the results indicate that the variance is not homogeneous.

Table 7. Analysis Post Hoc. Comparisons by cultures.

\begin{tabular}{|c|c|c|c|c|c|c|}
\hline \multicolumn{2}{|c|}{ Dependent Variable } & $\begin{array}{c}(I) \\
\text { Administrative } \\
\text { Culture }\end{array}$ & $\begin{array}{l}\text { (J) Administrative } \\
\text { Culture }\end{array}$ & $\begin{array}{c}\text { Mean } \\
\text { Difference (I-J) }\end{array}$ & $\begin{array}{l}\text { Standard } \\
\text { Error }\end{array}$ & $P$ \\
\hline \multirow{5}{*}{ Block 1} & \multirow{5}{*}{ HSD de Tukey } & Anglo-Saxon & $\begin{array}{c}\text { Nordic } \\
\text { Southern European }\end{array}$ & $\begin{array}{l}0.20 \\
0.10\end{array}$ & $\begin{array}{l}0.04 \\
0.04\end{array}$ & 0.00 \\
\hline & & \multirow{2}{*}{ Nordic } & Anglo-Saxon & -0.20 & 0.04 & 0.00 \\
\hline & & & Soument curopedan & & 0.04 & \\
\hline & & Southern & Anglo-Saxon & -0.10 & 0.04 & 0.03 \\
\hline & & European & Nordic & 0.10 & 0.04 & 0.04 \\
\hline \multirow{6}{*}{ Block 2} & \multirow{6}{*}{ Games-Howell } & \multirow{2}{*}{ Anglo-Saxon } & Nordic & 0.39 & 0.04 & 0.00 \\
\hline & & & Southern European & 0.15 & 0.03 & 0.03 \\
\hline & & \multirow{2}{*}{ Nordic } & Anglo-Saxon & -0.39 & 0.04 & 0.00 \\
\hline & & & Southern European & -0.26 & 0.05 & 0.00 \\
\hline & & Southern & Anglo-Saxon & -0.12 & 0.04 & 0.03 \\
\hline & & European & Nordic & 0.26 & 0.05 & 0.00 \\
\hline \multirow{6}{*}{ Block 3} & \multirow{6}{*}{ HSD de Tukey } & \multirow{2}{*}{ Anglo-Saxon } & Nordic & 0.31 & 0.05 & 0.00 \\
\hline & & & Southern European & 0.15 & 0.04 & 0.00 \\
\hline & & \multirow{2}{*}{ Nordic } & Anglo-Saxon & -0.31 & 0.05 & 0.00 \\
\hline & & & Southern European & -0.15 & 0.05 & 0.01 \\
\hline & & Southern & Anglo-Saxon & -0.15 & 0.05 & 0.00 \\
\hline & & European & Nordic & 0.15 & 0.05 & 0.01 \\
\hline \multirow{6}{*}{ Block 4} & \multirow{6}{*}{ HSD de Tukey } & \multirow{2}{*}{ Anglo-Saxon } & Nordic & 0.09 & 0.07 & 0.37 \\
\hline & & & Southern European & 0.02 & 0.06 & 0.90 \\
\hline & & \multirow{2}{*}{ Nordic } & Anglo-Saxon & -0.09 & 0.07 & 0.37 \\
\hline & & & Southern European & -0.06 & 0.07 & 0.60 \\
\hline & & Southern & Anglo-Saxon & -0.02 & 0.06 & 0.90 \\
\hline & & European & Nordic & 0.06 & 0.07 & 0.60 \\
\hline
\end{tabular}

As we can observe, in line with the first results for general, social and economic information, this new statistical analysis also reveals statistically significant differences between governments that belong to the three analysed cultural contexts. However, we have not obtained significant evidence of these differences in the case of environmental sustainability.

Finally, we examined the most significant differences using individual values for each item (Appendix A). In Anglo-Saxon governments, the information that achieves the lowest level of dissemination is originated in countries in which activities in connection with and information regarding internal promotion policies are developed. In contrast, in Southern European governments, the lowest publication levels correspond to pension commitments to employees. In Nordic governments, the least disseminated topics involve average payment periods and criteria for the identification of stakeholders. It is noteworthy that the percentage spent on local suppliers divided by total expenditures is not published in any of the three analysed contexts.

Regarding the distances between Anglo-Saxon and Southern European cases, the greatest differences stem from employee pension obligations and the priorities assigned to the aspects addressed in the information supplied. In contrast, the Anglo-Saxon-Nordic principal differences are not related to these topics. Rather, they focus on financial risks, the mean payment period, future calls for tenders and capital expenditures according to financial classifications. However, Southern European-Nordic differences are centred current calls for tenders for the supply and grants offers for non-profit organisations. 


\section{Discussion}

Our initial findings build on the conclusions of previous studies [44,45,47], which empirically confirmed the role of local government websites in the dissemination of financial information but did not study their specific role as instruments for publishing sustainability information. However, our results also indicate a need for significant improvements because the transparency indices do not reach $100 \%$, which would be desirable according to the questionnaire used. In sum, information is most deficient in the area of environmental sustainability, according to poor results found out by Hawrysz and Foltys [66] and Genus [67], whereas the general information that is published most closely aligns with the items recommended by international bodies.

Likewise, if we contrast the index for each country (Table 5) with data from the Global Right to Information Rating [13], our results are in line with validity and scores for Anglo-Saxon government legal frameworks, which score highest (Table 1). However, Nordic governments do not achieve transparency sustainability indices commensurate with their positions in this ranking system. Because their transparency laws were adopted earlier and their legal frameworks are of a higher quality, they should be ranked ahead of the Southern European governments. These comparisons within our empirical results suggest that the number of years that transparency laws have been in effect influences sustainability transparency to a substantially lesser degree than the suitable development of concrete legal guidelines regarding access to government information.

Similarly, a comparison of the country ranking derived from our results (Table 5) with the ranking of transparency legal framework development levels (using relative scores with a maximum of 150 (Table 1) reveals different situations depending on cultural context. In Anglo-Saxon and Southern European countries, the development of legal frameworks is more advanced than the level of sustainability transparency. However, differences are more pronounced in most Nordic countries than in Anglo-Saxon and Southern European countries. These differences between administrative cultures indicate that a government's commitment and manner of implementing transparency are decisive elements for sustainability transparency, which suggests that the conclusions of previous studies should be developed [25,32].

On the other hand, the results of comparing transparency index in pairs (i.e., two by two) (Table 3) appear to corroborate the conclusions of studies, such as those by Kickert [23] or Lozano et al. [43], that characterise the Nordic style of government as a mixed style (with Anglo-Saxon and Southern European cultural influences). Our results also represent advances of previous findings. From our results, it seems that positive Anglo-Saxon cultural influence on Nordic governments has been substantially stronger with respect to the dissemination of environmental information. However, the negative effect of Southern European culture has been stronger regarding the disclosure of economic information. Nevertheless, we have not obtained empirical evidence to contradict the findings of Navarro and Rodríguez [22] or Kickert [23], who concluded that the greatest differences between administrative cultures are between Anglo-Saxon and Southern European countries.

Finally, our results require further examination of prior findings [29-31], which drew conclusions regarding the influence of administrative cultures on the level of government openness toward citizens and on the commitment of local government leaders to transparency of information. In addition to the specific effect of cultural context on sustainability transparency practices, our findings support that this effect depends on the type of sustainability information because, as one can observe in each cultural context, the commitment of local government leaders to the disclosure of each type of information (i.e., general, economic, social, environmental) is not equal for the four analysed blocks.

\section{Conclusions}

Currently, sustainability of public policies and online government transparency have drawn substantial interest from stakeholders (e.g., citizens, politicians, managers and academics). In fact, diverse international bodies (the United Nations, the OECD, the G-20, the EU, IFAC, the World 
Bank) recommend that governments adopt good governance practices that favour public policies of sustainability by urging transparency with respect to economic, social and environmental information.

Although prior studies have analysed the dissemination of financial information on local government websites in specific countries, comparative analysis of sustainability transparency has not received the necessary attention. However, various prior studies and declarations from international bodies have recognised the timeliness and value of analysing practices regarding the dissemination of sustainability information via the comparative study of different cultural contexts because of the impact of tradition and administrative reforms in each country on the commitment of government leaders to communication with citizens and to providing access to public information.

This paper analyses the sustainability information published on the websites of 72 local governments, which were separated into three groups to represent the three European cultural contexts (i.e., Anglo-Saxon, Southern European and Nordic). A total of 10 countries were studied. Following the generally accepted international guidelines and through an analysis of website content, our empirical results reveal that the sustainability transparency of the group of analysed local governments reaches an intermediate level: $58.05 \%$ convergence with international guidelines.

As previous studies indicated, this level illustrates that websites serve as drivers of sustainability transparency and suggests the need to adopt measures to strengthen the dissemination of sustainability information among local governments in Europe.

However, our empirical analysis indicates that deficiencies in sustainability information are not similar across the three administrative cultures. This outcome suggests that the best instruments to encourage sustainability transparency could be different in the three analysed contexts.

No local government provides all the information needed to respond to the four dimensions of sustainability. Our results indicate that the most transparent local governments are the Anglo-Saxon, followed by the Southern European and, in third position, the Nordic. These results are consistent with those of prior studies that established the influence of administrative traditions on government openness to citizens and commitment to transparency. However, our findings extend the conclusions of previous studies because in addition to contrasting the specific influence of cultural context on sustainability transparency, we empirically demonstrate that the effect of this influence depends on the type of information: general, economic, social and environmental. In fact, the differences materialise in the types of sustainability information because priorities of local governments depend on cultural context. Anglo-Saxon and Nordic local governments have a greater need to improve environmental information, whereas the primary deficiency among Nordic local governments concerns economic information.

Extending the analysis of cultural contexts, the comparison of our empirical results with the Global Right to Information Rating [13], which studies transparency laws in 102 countries, enables us to obtain new findings. First, one might think that the number of years that transparency laws have been in effect (i.e., the year such a law was passed) could encourage the dissemination of government information because government leaders have dedicated more time to putting such laws into effect. However, our analysis provides empirical evidence that the amount of time that transparency laws have been in effect does not independently determine sustainability transparency.

In fact, although the oldest transparency laws in effect are those of Nordic countries and the most recent laws are those of Anglo-Saxon governments, our results reveal that Anglo-Saxon local governments have higher levels of sustainability transparency than Nordic local governments. In addition, Southern European local government sustainability transparency is also greater than that of Nordic countries, although their transparency laws are substantially more recent.

Second, if we compare our transparency indices with the values provided by the Global Right to Information Rating [13] regarding the quality of transparency laws in different countries, we can verify that the legal advance provided by each law can influences sustainability transparency. Anglo-Saxon governments appear to value the quality of their transparency laws more highly than Southern European governments, which appears to have encouraged greater sustainability transparency. 
However, certain Nordic countries exhibit higher levels than Anglo-Saxon governments, although Nordic governments exhibit a lower level of sustainability transparency for all types of information except environmental information.

All of these findings induce us to think that political decisions to improve sustainability transparency should be different in each of the three analysed cultural contexts, corroborating conclusions highlights by Genus [67]. In the Southern European governments, which present the lowest-quality legal framework regarding access to government information, we can deduce a need to develop guidelines regarding government transparency, primarily in matters such as scope, procedure requests, exceptions and refusals as well as appeals. To this end, politicians responsible for transparency law reforms could regard regulations from Ireland, the United Kingdom or Finland as models when adopting measures to incentivise citizen participation in public affairs.

However, in the case of Anglo-Saxon countries, which have a higher-quality legal framework, it would be worthwhile to motivate local governments regarding the advantages of using existing legal tools to strengthen sustainability transparency, with a particular emphasis on its use to improve citizen trust in government, as the literature has demonstrated. Progress in the study of the criteria for stakeholder selection would be particularly useful, as well as detailed analyses of information requests for each block of sustainability, with special attention devoted to environmental sustainability.

Finally, the case of Nordic governments is distinct. The legal frameworks of such governments regarding transparency are of a higher quality than those of Southern European countries. However, their laws are old, which suggests the need to undertake regulatory reforms that better fit the current demand of stakeholders of information. In this process, the Anglo-Saxon legal model could serve as a better reference than the Southern European model. Likewise, Finland's legal framework, which is of the highest quality of the 10 studied countries, could also be a useful reference, despite its seniority.

In the Table 8 are summarized the principal suggestions to administrative cultures.

Table 8. Summary of suggestions to administrative cultures.

\begin{tabular}{|c|c|c|c|}
\hline \multirow{6}{*}{ Suggestions } & \multicolumn{3}{|c|}{ General } \\
\hline & \multicolumn{3}{|c|}{ To adopt measures to strengthen the dissemination of sustainability information } \\
\hline & Anglo-Saxon & Nordic & Sourthern European \\
\hline & \multicolumn{2}{|c|}{ To improve environmental information } & - \\
\hline & $\begin{array}{l}\text { To motivate local governments to } \\
\text { use existing legal tools to strengthen } \\
\text { sustainability transparency }\end{array}$ & $\begin{array}{l}\text { To undertake } \\
\text { regulatory reforms }\end{array}$ & $\begin{array}{l}\text { To develop guidelines } \\
\text { regarding government } \\
\text { transparency }\end{array}$ \\
\hline & $\begin{array}{l}\text { To do detailed analyses of } \\
\text { information requests for each block } \\
\text { of sustainability }\end{array}$ & & $\begin{array}{c}\text { To incentive participation } \\
\text { in public affairs }\end{array}$ \\
\hline
\end{tabular}

Some of the limitations of this study can give rise to various future lines of work. First, increasing the sample will allow us to improve the robustness of the results since the current sample limits the conclusions to local governments of big European cities belonging to three types of administrative cultures. The study could be extended to other cities and other cultures, such as the Germanic. Second, this research has analysed the lack of information but has not studied the reasons for this absence; this point should be researched. In addition, the information analysed is static and unidirectional; it would be necessary to study the dialogue of the governments with the stakeholders. Third, this investigation focuses on the amount of information provided and on its nature, but it would be also necessary, in future studies, to analyse the relationship between the kind of information in each dimension and the initiatives reflected in strategy.

Acknowledgments: The authors wishes to thank the anonymous reviewers for comments on an early draft of this paper. All views expressed in the paper, and any omissions or errors therein, are those of the author. 
Author Contributions: The authors had an equal contribution to this research. All authors read and approved the final manuscript.

Conflicts of Interest: The author declares no conflict of interest.

\section{Appendix}

Table A1. Disclosure Information of Local Governments by Administrative Culture.

\begin{tabular}{|c|c|c|c|}
\hline Information & Anglo-Saxon Countries & Nordic Countries & $\begin{array}{c}\text { Southern European } \\
\text { Countries }\end{array}$ \\
\hline \multicolumn{4}{|c|}{ Block 1: General Information about Sustainability } \\
\hline \multicolumn{4}{|l|}{ 1. Strategy and Analysis } \\
\hline $\begin{array}{l}\text { 1. Is a statement made by the Head of Government } \\
\text { on the importance of sustainability for the LG and } \\
\text { its strategy? }\end{array}$ & $67 \%$ & $33 \%$ & $69 \%$ \\
\hline $\begin{array}{l}\text { 2. Does this statement set out priorities, strategies } \\
\text { and key factors for the short-medium term? }\end{array}$ & $67 \%$ & $24 \%$ & $65 \%$ \\
\hline $\begin{array}{l}\text { 3. Does this statement address long-term trends } \\
\text { relevant to priorities concerning sustainability? }\end{array}$ & $67 \%$ & $19 \%$ & $58 \%$ \\
\hline $\begin{array}{l}\text { 4. Does this statement include events, } \\
\text { achievements and failures during the period } \\
\text { in question? }\end{array}$ & $50 \%$ & $10 \%$ & $31 \%$ \\
\hline $\begin{array}{l}\text { 5. Does this statement include goals-oriented } \\
\text { performance perspectives? }\end{array}$ & $67 \%$ & $5 \%$ & $54 \%$ \\
\hline $\begin{array}{l}\text { 6. Does this statement include challenges and } \\
\text { targets for the coming year and the forthcoming } \\
3-5 \text { years? }\end{array}$ & $58 \%$ & $14 \%$ & $58 \%$ \\
\hline \multicolumn{4}{|l|}{ 2. Organization Profile } \\
\hline 7. Does the RG own trademarks? & $33 \%$ & $86 \%$ & $19 \%$ \\
\hline 8. Are different areas clearly defined? & $100 \%$ & $95 \%$ & $100 \%$ \\
\hline $\begin{array}{l}\text { 9. Do RG officials have area-defined } \\
\text { responsibilities? }\end{array}$ & $100 \%$ & $95 \%$ & $100 \%$ \\
\hline $\begin{array}{l}\text { 10. Is the situation of the regional seat of } \\
\text { government stated? }\end{array}$ & $92 \%$ & $81 \%$ & $100 \%$ \\
\hline $\begin{array}{l}\text { 11. Is a statement made of the number of countries } \\
\text { in which significant activities are carried out? }\end{array}$ & $8 \%$ & $57 \%$ & $58 \%$ \\
\hline 12. Is the number of employees stated? & $33 \%$ & $76 \%$ & $58 \%$ \\
\hline $\begin{array}{l}\text { 13. Have significant changes taken place in the RG } \\
\text { structure or size? }\end{array}$ & $17 \%$ & $19 \%$ & $12 \%$ \\
\hline $\begin{array}{l}\text { 14. Has the RG been awarded prizes or other } \\
\text { recognition during the period in question? }\end{array}$ & $42 \%$ & $19 \%$ & $27 \%$ \\
\hline \multicolumn{4}{|l|}{ 3. Information Parameters } \\
\hline $\begin{array}{l}\text { 15. Is a statement made of the period } \\
\text { corresponding to the information supplied? }\end{array}$ & $100 \%$ & $76 \%$ & $96 \%$ \\
\hline $\begin{array}{l}\text { 16. Is the date of publication of this } \\
\text { information stated? }\end{array}$ & $100 \%$ & $71 \%$ & $88 \%$ \\
\hline $\begin{array}{l}\text { 17. Is the presentation frequency of this } \\
\text { information stated? }\end{array}$ & $100 \%$ & $95 \%$ & $92 \%$ \\
\hline $\begin{array}{l}\text { 18. Is there a liaison person for questions } \\
\text { concerning the information supplied? }\end{array}$ & $100 \%$ & $86 \%$ & $100 \%$ \\
\hline $\begin{array}{l}\text { 19. Does the information supplied include dates of } \\
\text { specific interest for suppliers and users? }\end{array}$ & $100 \%$ & $90 \%$ & $96 \%$ \\
\hline $\begin{array}{l}\text { 20. Is priority assigned to the aspects addressed in } \\
\text { the information supplied? }\end{array}$ & $83 \%$ & $57 \%$ & $31 \%$ \\
\hline
\end{tabular}


Table A1. Cont.

\begin{tabular}{|c|c|c|c|}
\hline Information & Anglo-Saxon Countries & Nordic Countries & $\begin{array}{l}\text { Southern European } \\
\quad \text { Countries }\end{array}$ \\
\hline \multicolumn{4}{|l|}{ 4. Government Undertakings and Stakeholder Participation } \\
\hline $\begin{array}{l}\text { 21. Is there a given person or government body responsible } \\
\text { for defining organization strategy? }\end{array}$ & $100 \%$ & $81 \%$ & $96 \%$ \\
\hline $\begin{array}{l}\text { 22. Does the chief official hold any other public or } \\
\text { private post? }\end{array}$ & $33 \%$ & $5 \%$ & $19 \%$ \\
\hline $\begin{array}{l}\text { 23. Do there exist works' committees or workers' } \\
\text { representatives? }\end{array}$ & $8 \%$ & $52 \%$ & $69 \%$ \\
\hline $\begin{array}{l}\text { 24. Are the stakeholders included in the } \\
\text { information supplied? }\end{array}$ & $75 \%$ & $90 \%$ & $54 \%$ \\
\hline $\begin{array}{l}\text { 25. Does the information presented include the } \\
\text { Government's programme? }\end{array}$ & $58 \%$ & $24 \%$ & $46 \%$ \\
\hline $\begin{array}{l}\text { 26. Is a statement made of the Government's programme } \\
\text { commitments that have been fulfilled? }\end{array}$ & $58 \%$ & $10 \%$ & $31 \%$ \\
\hline 27. Does the governing party have an absolute majority? & $33 \%$ & $24 \%$ & $35 \%$ \\
\hline $\begin{array}{l}\text { 28. Are stakeholder selection and identification criteria } \\
\text { included in the information supplied? }\end{array}$ & $25 \%$ & $0 \%$ & $15 \%$ \\
\hline \multicolumn{4}{|c|}{ Block 2: Economic Information about Sustainability } \\
\hline \multicolumn{4}{|l|}{ 5. Economic Indicators } \\
\hline $\begin{array}{l}\text { 29. Is an expenditure forecast/beneficiary } \\
\text { population published? }\end{array}$ & $33 \%$ & $14 \%$ & $73 \%$ \\
\hline 30. Is a revenue forecast/beneficiary population published? & $33 \%$ & $14 \%$ & $69 \%$ \\
\hline $\begin{array}{l}\text { 31. Are revenues transferred from other public } \\
\text { administrations/total revenues published? }\end{array}$ & $83 \%$ & $38 \%$ & $85 \%$ \\
\hline 32. Is the level of fiscal pressure published? & $75 \%$ & $52 \%$ & $69 \%$ \\
\hline $\begin{array}{l}\text { 33. Is gross expenditure, detailed by type of } \\
\text { payment, published? }\end{array}$ & $67 \%$ & $76 \%$ & $38 \%$ \\
\hline $\begin{array}{l}\text { 34. Is gross expenditure, detailed by financial } \\
\text { classification, published? }\end{array}$ & $100 \%$ & $57 \%$ & $81 \%$ \\
\hline $\begin{array}{l}\text { 35. Is capital expenditure, detailed by financial classification, } \\
\text { published? }\end{array}$ & $100 \%$ & $33 \%$ & $65 \%$ \\
\hline 36. Is the cost of service provision published? & $75 \%$ & $48 \%$ & $27 \%$ \\
\hline 37. Is the mean payment period stated? & $67 \%$ & $0 \%$ & $38 \%$ \\
\hline $\begin{array}{l}\text { 38. Is a statement made of current calls for tenders for the } \\
\text { supply of goods or services? }\end{array}$ & $75 \%$ & $5 \%$ & $100 \%$ \\
\hline 39. Is the profile of contracting companies published? & $58 \%$ & $29 \%$ & $92 \%$ \\
\hline 40. Is a statement made of future calls for tenders? & $67 \%$ & $0 \%$ & $88 \%$ \\
\hline 41. Is the policy on internal promotion published? & $17 \%$ & $5 \%$ & $35 \%$ \\
\hline 42. Are staff training facilities published? & $33 \%$ & $10 \%$ & $46 \%$ \\
\hline $\begin{array}{l}\text { 43. Is the Government's capacity for legal indebtedness } \\
\text { made public? }\end{array}$ & $17 \%$ & $52 \%$ & $35 \%$ \\
\hline 44. Is a statement made of future financial risk? & $83 \%$ & $0 \%$ & $38 \%$ \\
\hline 45. Is a statement made of public assets and insured goods? & $17 \%$ & $0 \%$ & $27 \%$ \\
\hline 46. Is an audit report published? & $100 \%$ & $52 \%$ & $54 \%$ \\
\hline 47. Are data given on subsidies received? & $83 \%$ & $38 \%$ & $58 \%$ \\
\hline 48. Are the annual accounts published? & $100 \%$ & $67 \%$ & $62 \%$ \\
\hline $\begin{array}{l}\text { 49. Is a report published on the accounts policy } \\
\text { implemented? }\end{array}$ & $92 \%$ & $67 \%$ & $42 \%$ \\
\hline 50. Is a report published on the expenditure forecast? & $100 \%$ & $33 \%$ & $85 \%$ \\
\hline 51. Does the latter include medium-term perspectives? & $83 \%$ & $29 \%$ & $65 \%$ \\
\hline $\begin{array}{l}\text { 52. Are the following key economic assumptions and } \\
\text { forecast made public: GDP growth, employment, } \\
\text { unemployment, inflation and rates of interest? }\end{array}$ & $75 \%$ & $71 \%$ & $62 \%$ \\
\hline
\end{tabular}


Table A1. Cont.

\begin{tabular}{|c|c|c|c|}
\hline Information & Anglo-Saxon Countries & Nordic Countries & $\begin{array}{l}\text { Southern European } \\
\text { Countries }\end{array}$ \\
\hline \multicolumn{4}{|c|}{ Block 3: Social Information about Sustainability } \\
\hline \multicolumn{4}{|l|}{ 6. Social Indicators } \\
\hline 53. Is the offer of services made public? & $100 \%$ & $90 \%$ & $96 \%$ \\
\hline $\begin{array}{l}\text { 54. Is a statement made on expenditure incurred in the area } \\
\text { of social issues? }\end{array}$ & $75 \%$ & $52 \%$ & $73 \%$ \\
\hline $\begin{array}{l}\text { 55. Is a subsidies announcement made for } \\
\text { business activities? }\end{array}$ & $100 \%$ & $71 \%$ & $88 \%$ \\
\hline $\begin{array}{l}\text { 56. Is a statement made on pensions obligations } \\
\text { to employees? }\end{array}$ & $67 \%$ & $62 \%$ & $0 \%$ \\
\hline $\begin{array}{l}\text { 57. Are grants offers to neighbourhood associations } \\
\text { made public? }\end{array}$ & $83 \%$ & $19 \%$ & $73 \%$ \\
\hline 58. Are offers of public employment made public? & $92 \%$ & $52 \%$ & $85 \%$ \\
\hline 59. Are grants offers to NGOs made public? & $75 \%$ & $14 \%$ & $77 \%$ \\
\hline 60. Are indicators of effectiveness and efficiency published? & $67 \%$ & $52 \%$ & $65 \%$ \\
\hline $\begin{array}{l}\text { 61. Is information given on initial wage (when staff are } \\
\text { hired)/local minimum wage? }\end{array}$ & $42 \%$ & $5 \%$ & $15 \%$ \\
\hline $\begin{array}{l}\text { 62. Is information given on expenditure on local } \\
\text { suppliers/total expenditure? }\end{array}$ & $0 \%$ & $0 \%$ & $0 \%$ \\
\hline
\end{tabular}

\begin{tabular}{|c|c|c|c|}
\hline \multicolumn{4}{|c|}{ Block 4: Environmental Information about Sustainability } \\
\hline 7. Environmental Indicators & & & \\
\hline $\begin{array}{l}\text { 63. Is information published on the initiatives taken to } \\
\text { alleviate the environmental impact of products and services? }\end{array}$ & $100 \%$ & $76 \%$ & $62 \%$ \\
\hline 64. Is the degree of reduction of the above impact stated? & $67 \%$ & $62 \%$ & $27 \%$ \\
\hline $\begin{array}{l}\text { 65. Is a statement made of the direct consumption of energy } \\
\text { obtained from primary sources? }\end{array}$ & $33 \%$ & $29 \%$ & $54 \%$ \\
\hline $\begin{array}{l}\text { 66. Is a statement made of the consumption of } \\
\text { intermediate energy? }\end{array}$ & $25 \%$ & $24 \%$ & $50 \%$ \\
\hline $\begin{array}{l}\text { 67. Is a statement made of the actions taken to increase } \\
\text { savings via conservation or increased efficiency? }\end{array}$ & $92 \%$ & $71 \%$ & $69 \%$ \\
\hline $\begin{array}{l}\text { 68. Is information published on initiatives taken to promote } \\
\text { products and services that are energy efficient or based on } \\
\text { the use of renewable energies? }\end{array}$ & $100 \%$ & $71 \%$ & $77 \%$ \\
\hline $\begin{array}{l}\text { 69. Is information published on reductions in energy } \\
\text { consumption as a result of the above initiatives? }\end{array}$ & $33 \%$ & $33 \%$ & $38 \%$ \\
\hline $\begin{array}{l}\text { 70. Is information published on the initiatives taken to } \\
\text { reduce indirect energy consumption? }\end{array}$ & $75 \%$ & $52 \%$ & $58 \%$ \\
\hline $\begin{array}{l}\text { 71. Is information published on reductions achieved by the } \\
\text { above initiatives? }\end{array}$ & $17 \%$ & $19 \%$ & $35 \%$ \\
\hline $\begin{array}{l}\text { 72. Is information published on the different sources of } \\
\text { water supply employed, and the volume obtained from } \\
\text { each source? }\end{array}$ & $8 \%$ & $38 \%$ & $46 \%$ \\
\hline $\begin{array}{l}\text { 73. Is information published on the percentage and total } \\
\text { volume of water that is recycled and reused in the } \\
\text { community? }\end{array}$ & $17 \%$ & $19 \%$ & $35 \%$ \\
\hline $\begin{array}{l}\text { 74. Is information published on the disposal of waste water } \\
\text { by the community? }\end{array}$ & $25 \%$ & $29 \%$ & $35 \%$ \\
\hline $\begin{array}{l}\text { 75. Is information published on the total and type of } \\
\text { expenditure on environmental investment? }\end{array}$ & $58 \%$ & $52 \%$ & $81 \%$ \\
\hline
\end{tabular}

\section{References}

1. Mol, A.P. China's Transition to Sustainability. Which direction to take? In Routledge International Handbook of Sustainable Development; Routledge: Abingdon, UK, 2015; pp. 351-363.

2. Beare, D.; Buslovich, R.; Searcy, C. Linkages between corporate sustainability reporting and public policy. Corp. Soc. Responsib. Environ. Manag. 2014, 21, 336-350. [CrossRef] 
3. Krause, A.; Golovin, D.; Converse, S. Sequential Decision Making in Computational Sustainability through Adaptive Submodularity. AI Mag. 2014, 35, 8-18.

4. G-20. G-20 Leaders' Declaration. Available online: www.g20.org (accessed on 20 February 2015).

5. International Federation of Accountants (IFAC). Accountability, Sustainability, and Growth Recommendations for the G-20 Leaders' Summit. 2013. Available online: http://www.ifac.org/ publications-resources/accountability-sustainability-and-growth-recommendations-g-20-leaders-summit (accessed on 15 May 2014).

6. EU. European Commission. Transparency Portal. 2015. Available online: http://ec.europa.eu/transparency/ index_es.htm (accessed on 10 May 2016).

7. EU. Fiscal Sustainability Report 2012. Available online: http://ec.europa.eu/economy_finance/ publications/european_economy/2012/pdf/ee-2012--8_en.pdf (accessed on 15 May 2014).

8. World Bank. Overview: Understanding, Measuring and Overcoming Poverty. 2008. Available online: http:/ / web.worldbank.org (accessed on 10 February 2012).

9. Erkkila, T. Global Governance Indices as Policy Instruments: Actionability, transparency and comparative policy analysis. J. Comp. Policy Anal. 2015. [CrossRef]

10. Navarro, A.; de los Ríos, A.; Ruiz, M.; Tirado, P. Transparency of Sustainability Information in Local Governments: English-speaking and Nordic cross-country analysis. J. Clean. Prod. 2014, 64, 495-504. [CrossRef]

11. Greco, G.; Sciulli, N.; D'Onza, G. The influence of stakeholder engagement on sustainability reporting: Evidence from Italian local councils. Public Manag. Rev. 2015, 17, 465-488. [CrossRef]

12. Williams, B.; Wimshurst, T.; Clift, R. Sustainability reporting by local government in Australia: Current and future prospects. Account. Forum 2011, 35, 176-186. [CrossRef]

13. Centre for Law and Democracy. Global Right to Information Rating. 2015. Available online: www.rti-rating. org (accessed on 2 May 2016).

14. Worthy, B. Some are more open than others: Comparing the impact of the freedom of information act 2000 on local and central government in the UK. J. Comp. Policy Anal. 2013, 15, 395-414. [CrossRef]

15. Vleugels, R. Overview of All FOI Law around the World-2012 Update. Available online: http://www. right2info.org/resources/publications/laws-2 (accessed on 10 May 2014).

16. Rodríguez Bolívar, M.P.; Navarro Galera, A.; Alcaide Muñoz, L.; López Subirés, M.D. Analyzing Forces to the Financial Contribution of Local Governments to Sustainable Development. Sustainability 2016, 8, 925. [CrossRef]

17. Dunion, K. Freedom of Information in Scotland in Practice; Dundee University Press: Dundee, Scotland, 2011.

18. Armstrong, C.L. Providing a Clearer View: An examination of transparency on local government websites. Gov. Inf. Q. 2011, 28, 11-16. [CrossRef]

19. García-Sánchez, I.; Frías Aceituno, J.V.; Rodríguez Domínguez, L. Determinants of corporate social disclosure in Spanish local governments. J. Clean. Prod. 2013, 39, 60-72. [CrossRef]

20. Alcaraz-Quiles, F.J.; Navarro-Galera, A.; Ortiz-Rodríguez, D. Factors determining online sustainability reporting by local governments. Int. Rev. Adm. Sci. 2015, 81, 79-109. [CrossRef]

21. Benito, B.; Bastida, F. Budget Transparency, Fiscal Performance, and Political Turnout: An international approach. Public Adm. Rev. 2009, 69, 403-417. [CrossRef]

22. Navarro, A.; Rodríguez, M.P. Utilidad del Modelo de Valoración de las IPSAS para la Rendición de Cuentas de los Gobiernos: La perspectiva de los OCEX. Span. J. Financ. Account. 2011, 149, 125-162.

23. Kickert, W. Distinctive Characteristics of State and Administrative Reform in Southern Europe. In Proceedings of the IRSPM Conference, Postdam, Germany, 2-4 April 2007.

24. Christensen, T.; Lægreid, P. Transcending New Public Management: The Transformation of Public Sector Reforms; Ashgate: Aldershot, UK, 2007.

25. Haque, M.S. Modernising government: The way forward-An analysis. Int. Rev. Adm. Sci. 2006, 72, 319-325. [CrossRef]

26. Alam, M.; Nandam, R. Public sector reform and accounting change in a cultural environment. In ASBBS 7th International Conference; American Society for Business \& Behavioural Sciences, 2004; pp. 53-63. Available online: http:/ / researchonline.jcu.edu.au/14737/ (accessed on 15 March 2017). 
27. Caridad, M. The system and the use of accrual accounting in the local authorities of the United Kingdom, Sweden and Spain. In Proceedings of the 28th Annual Congress of the European Accounting Association-Collected Abstracts, Gothenburg, Sweden, 18-20 May 2005.

28. Bryson, J.M.; Crosby, B.C.; Bloomberg, L. Public Value Governance: Moving beyond traditional public administration and the New Public Management. Public Adm. Rev. 2014, 74, 445-456. [CrossRef]

29. Kettl, D.F. Modernising government: The way forward-A comment. Int. Rev. Adm. Sci. 2006, 72, $313-317$. [CrossRef]

30. Pez Casasnovas, G. La calidad del gasto público y su influencia en el desarrollo económico: Una validación empírica para los países de la OCDE 1979-2005. Hacienda Pública Esp. 2010, 193, 9-48.

31. Akesson, M.; Edvarsson, B. Effects of e-Government on Service Design as Perceived by Employees. Manag. Serv. Qual. 2008, 18, 457-478.

32. Rodríguez, M.P.; Caba, M.C.; López, A.M. Cultural Contexts and Governmental Digital Reporting. Int. Rev. Adm. Sci. 2006, 32, 379-400.

33. Pina, V.; Torres, L.; Royo, S. Accountability as a differentiated value in supranational government. Am. Rev. Public Adm. 2010, 40, 742-760.

34. Organisation for Economic Co-operation and Development (OECD). In Search of Results: Performance Management Practices; PUMA/OEDC: Paris, France, 1997.

35. Organisation for Economic Co-operation and Development (OECD). Accounting for What? The Value of Accrual Accounting to the Public Sector; Occasional Papers on Public Management; OCDE: Paris, France, 1997.

36. Torres, L. Accounting and accountability: Recent developments in government financial information systems. Public Adm. Dev. 2004, 24, 447-456. [CrossRef]

37. Pina, V.; Torres, L.; Royo, S. Is e-government promoting convergence towards more accountable local governments. Int. Publ. Manag. J. 2010, 13, 350-380. [CrossRef]

38. Hammerschmid, G.; Meyer, R. Current initiatives and central actors in the Australian administrative reform process. In Proceedings of the European Group of Public Administration Annual Conference, Oeiras, Portugal, 3-6 September 2003.

39. Howlett, M. Administrative styles and regulatory reform: Institutional arrangements and their effects on administrative behavior. Int. Public Manag. J. 2004, 7, 317-333.

40. Kim, S.; Lee, J. E-Participation Transparency, and Trust in Local Government. Public Adm. Rev. 2012, 72, 819-828. [CrossRef]

41. Arellano-Gault, D.; del Castillo-Vega, A. Maturation of Public Administration in a Multicultural Environment: Lessons from the Anglo-Saxon, Latin, and Scandinaviam political traditions. Int. J. Public Adm. 2004, 27, 519-528. [CrossRef]

42. CSR Europe. A Guide to CSR in Europe. Country Insights by CSR Europe's National Partner Organisations. 2010. Available online: http://www.csreurope.org/data/files/guide_to_csr_2010.pdf (accessed on 7 January 2012).

43. Lozano, J.; Albareda, L.; Ysa, T. ¿Qué pueden hacer los gobiernos para promover la responsabilidad social de la empresa (RSE)? CIRIEC Esp. Rev. Econ. Pública Soc. Co-op. 2005, 53, 53-64.

44. Alcaide Muñoz, L.; Rodríguez Bolivar, M.P. Determining factors of transparency and accountability in local governments: A meta-analytic study. Lex Localis 2015, 13, 129-160. [CrossRef]

45. Bonsón, E.; Torres, L.; Royo, S.; Flores, F. Local e-government 2.0: Social media and corporate transparency in municipalities. Gov. Inf. Q. 2012, 29, 123-132. [CrossRef]

46. International Council for Local Environmental Initiatives (ICLEI). Measuring up: A Detailed Look at the Impressive Goals and Climate Action Progress of U.S. Cities and Countries; ICLEI: Boston, MA, USA, 2009.

47. Royo, S.; Yetano, A.; Acerete, B. E-Participation and Environmental Protection: Are Local Government Really Commited? Public Adm. Rev. 2013, 74, 87-98. [CrossRef]

48. Organisation for Economic Co-operation and Development (OECD). Intellectual Assets and Value Creation: Implications for Corporate Reporting; Corporate Affairs Division, Directorate for Financial and Enterprise Affairs, OECD: Paris, France, 2006.

49. Fernández-Feijoo, B.; Romero, S.; Ruiz, S. Commitment to corporate social responsibility measured through global reporting initiative reporting: Factors affecting the behavior of companies. J. Clean. Prod. 2014, 81, 244-254. [CrossRef] 
50. Estevez, E.; Janowski, T. Electronic Governance for Sustainable Development-Conceptual framework and state of research. Gov. Inf. Q. 2013, 30, S94-S109. [CrossRef]

51. Janowski, T. Digital government evolution: From transformation to contextualization. Gov. Inf. Q. 2015, 32, 221-236. [CrossRef]

52. United Nations Global Compact (UNGC). What Is the Global Compact? Available online: http://www. unglobalcompact.org/ (accessed on 10 January 2012).

53. Global Reporting Initiative (GRI). G3 Sustainability Reporting Guidelines; Global Reporting Initiative: Amsterdam, The Netherlands, 2006.

54. Crognale, G. The Global Reporting Initiative G3 Sustainability Reporting Guidelines (Conclusion). Bus. Environ. 2009, 20, 11-14.

55. Bernhart, M. The rules of The Game. Commun. World 2009, 26, 25-28.

56. Global Reporting Initiative (GRI). Sector Supplement for Public Agencies; Global Reporting Initiative: Amsterdam, The Netherlands, 2010.

57. Global Reporting Initiative (GRI). G4 Sustainability Reporting Guidelines; Global Reporting Initiative: Amsterdam, The Netherlands, 2013.

58. Tirado-Valencia, P.; Rodero-Cosano, M.L.; Ruiz-Lozano, M.; Rios-Berjillos, A. Online sustainability information in European local governments: An explicative model to improve transparency. Online Inf. Rev. 2016, 40, 400-415. [CrossRef]

59. Dutta, S.; Lawson, R. Aligning Performance Evaluation and Reward Systems with Corporate Sustainability Goals. Cost Manag. 2009, 23, 15-23.

60. Navarro Galera, A.; Ortúzar Maturana, R.; Alcaraz Quiles, F.J. The life cycle costing viability for the economic assessment of military investments. Rev. Contab. Span. Account. Rev. 2016, 19, 169-180.

61. Zar, J.H. Biostatistical Analysis, 5th ed.; Pearson: Upper Saddle River, NJ, USA, 2010.

62. Engle, R. Corporate Social Responsibility in Host Countries: A Perspective from American Managers. Corp. Soc. Responsib. Environ. Manag. 2007, 14, 16-27. [CrossRef]

63. Kvanli, A.; Pavur, R.; Keeling, K. Business Statistics: A Microsoft Excel Integrated Approach; Thomson: Mason, OH, USA, 2003.

64. Fukuyama, F. Policy Paper. Against Corruption: A Collection of Essays; Prime Minister's Office: London, UK, 2016.

65. Transparency International. Corruption Perceptions Index. 2016. Available online: http://www. transparency.org/news/feature/corruption_perceptions_index_2016 (accessed on 14 February 2017).

66. Hawrysz, L.; Foltys, J. Environmental aspects of social responsibility of public sector organizations. Sustainability 2016, 8, 19. [CrossRef]

67. Genus, A. Governing Sustainability: A Discourse-Institutional Approach. Sustainability 2014, 6, $283-305$. [CrossRef]

(C) 2017 by the authors. Licensee MDPI, Basel, Switzerland. This article is an open access article distributed under the terms and conditions of the Creative Commons Attribution (CC BY) license (http:/ / creativecommons.org/licenses/by/4.0/). 